\title{
Memória
}

\section{Uma proposta editorial}

O resgate da memória da psiquiatria oferece a clínicos e pesquisadores perspectiva e humildade ${ }^{1}$, importantes antídotos de dogmatismos e modismos, sempre recorrentes em nossa disciplina. Desta forma, o exame do processo histórico é de valor estratégico para se avaliar criticamente as questões atuais da profissão, sejam elas clínicas, científicas, sociais, políticas ou epistemológicas.

Mas além de útil, recuperar a história da psiquiatria é também um empreendimento prazeroso. ${ }^{1}$ Talvez o simples deleite que a muitos proporciona uma viagem pelas origens já seja suficiente para justificar a seção. Investigar o passado implica quase sempre recontar histórias e quem, afinal, não se delicia com uma história bem contada!

Neste século a história da psiquiatria passou por pelo menos duas formas de reducionismo; de um lado, o presentismo, e de outro, algo que poderia ser denominado "análise externa ao conhecimento". Na perspectiva presentista, os fatos históricos são selecionados e dimensionados exclusivamente a partir dos conhecimentos atuais. ${ }^{2}$ Este tipo de abordagem histórica, geralmente realizada por professores de psiquiatria, professa um evoluir linear, cumulativo e triunfal dos conhecimentos psiquiátricos. A "análise externa", mais freqüentemente praticada por historiadores sociais e filósofos, analisa os impactos das instituições psiquiátricas sobre os pacientes e a sociedade (quase sempre com um tom condenatório), mas negligencia o desenvolvimento interno dos conhecimentos da disciplina. ${ }^{3}$ Recentemente, uma abordagem mais equilibrada e dialética parece vir ganhando terreno. ${ }^{4}$

De todo modo, qualquer que seja o enfoque, os fatos, processos e análises históricas estão muito longe de serem imparciais. A sua recuperação e exposição são, infelizmente ou não, altamente seletivos. Isto obriga que uma seção de memória da disciplina numa revista como esta deva ser necessariamente "aberta", abrigando as diversas leituras e seleções que os pesquisadores realizam. A seção "Memória da Psiquiatria" deverá dar prioridade a temas referentes à história da psiquiatria no Brasil, entretanto, artigos interessantes sobre a memória da psiquiatria em outras terras também serão acolhidos.

Que seja, portanto, bem-vindo este louvável esforço da Revista Brasileira de Psiquiatria, pela recuperação e

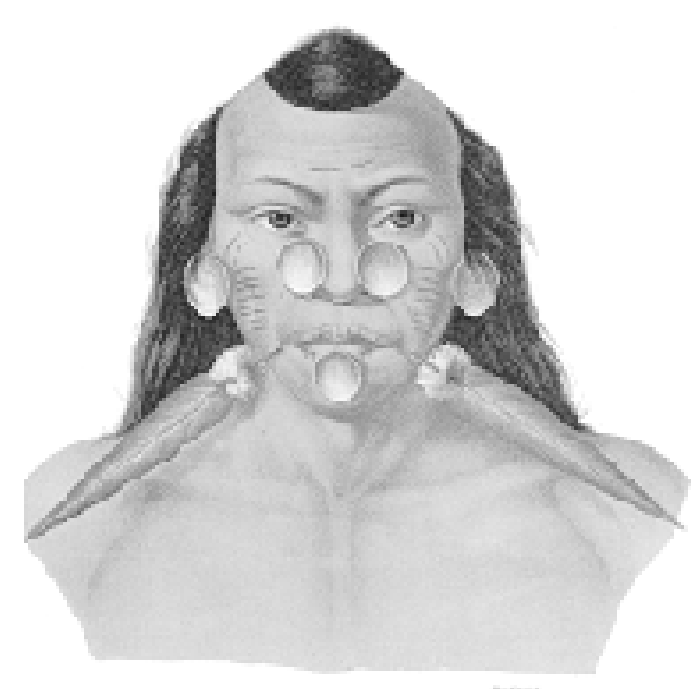

reavivamento crítico da memória de nossa profissão.

Para inaugurar a seção, foram selecionados trechos do livro "Natureza, doenças, medicina e remédios dos índios brasileiros", do naturalista alemão Carl Friedrich Philipp Von Martius (1794-1868), publicado em 1844. Nele, o autor descreve, além dos transtornos mentais, diversos aspectos do índio brasileiro, a configuração de muitos grupos étnicos, sua anatomia, temperamento, alimentos consumidos, longevidade, doenças prevalentes, geografia médica, plantas medicinais reais e míticas, métodos terapêuticos, e mesmo crenças e códigos que configuram uma verdadeira ética médica indígena. Encontram-se aqui, provavelmente, os primeiros relatos de doenças mentais em populações indígenas brasileiras. No texto observam-se algumas noções típicas do alienismo do início do século XIX, como a idéia de uma certa "indiscriminação" e "primitivismo" do psiquismo do indígena, a noção de que a doença mental seria muito rara entre eles, assim como a importância dos abalos emocionais na gênese da alienação mental. De grande interesse e originalidade é a apresentação do "Banzo" em índios, contraposta à dos escravos africanos.

Paulo Dalgalarrondo

Departamento de Psicologia Médica e Psiquiatria da Faculdade de Ciências Médicas da Universidade Estadual de Campinas

\section{Referências Bibliográficas}

1. Wertheimer M. Pequena história da psicologia. São Paulo (SP): Editora Nacional; 1989.

2. Schaaf A. História e verdade. São Paulo (SP): Ed. Martins Fontes; 1995.

3. Micale MS, Porter R. Discovering the history of Psychiatry. Oxford: Oxford University Press; 1994.

4. Berrios GE. The history of mental symptoms. Cambridge: Cambridge University Press; 1996. 